\title{
Diagnosing multiple short circuit switches faults in wind turbine doubly-fed induction generator
}

\author{
Sara Kharoubi, Lamiaa El Menzhi \\ Department of Electronics/Electrotechnical, National School of Applied Sciences, Abdelmalek Essaadi University, Tangier, Morocco
}

\begin{tabular}{|c|c|}
\hline Article Info & ABSTRACT \\
\hline & In the current paper, the inverter feeding doubly fed induction generator \\
\hline Received Jun 19, 2021 & $\begin{array}{l}\text { (DFIG) in the case of short circuit switches fault is presented. Defects } \\
\text { diagnosis is based on the so-called the Lissajous curves of DFIG rotor }\end{array}$ \\
\hline Revised Feb 3, 2022 & currents. For this purpose, the modeling of the variable speed wind energy \\
\hline Accepted Feb 10, 2022 & $\begin{array}{l}\text { conversion chain based on the DFIG, is firstly introduced, after that a } \\
\text { description of the voltage source inverter operating mode is presented. }\end{array}$ \\
\hline Keywords: & $\begin{array}{l}\text { Finally, rotor currents Lissajous curves are analyzed in case of a non- } \\
\text { defective and defective inverter. Simulation results were achieved using }\end{array}$ \\
\hline $\begin{array}{l}\text { Defects diagnosis } \\
\text { Doubly fed electric machine }\end{array}$ & $\begin{array}{l}\text { MATLAB^®- SIMULINK^^ }{ }^{\wedge} \text { package, thus confirming the efficiency of the } \\
\text { proposed method. }\end{array}$ \\
\hline
\end{tabular}

Inverters

Lissajous curves

Short circuit switches fault

Voltage source inverter

\section{Corresponding Author:}

Sara Kharoubi

Department of Electronics/Electrotechnical, National School of Applied Sciences, Abdelmalek Essaadi

University, Av. Khenifra, Tétouan 93000, Tangier 9000, Morocco

Email: sara.kharoubi@gmail.com
This is an open access article under the CC BY-SA license.

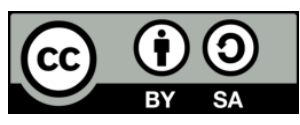

\section{INTRODUCTION}

Power electronics play major roles in wind energy. They are responsible for several functions such as starting the system, regulating turbine speed, interfacing turbine with the grid, regulating real and reactive powers, and controlling the system during disturbances [1]. The doubly fed induction generator (DFIG) has many benefits. This is possible due to its ability to supply power at constant voltage and frequency while the rotor speed varies [2], [3], which allows better wind capture, compared to fixed speed wind turbines.

The DFIG is a wound rotor induction generator, the stator winding of which are directly connected to the grid. The rotor winding is connected to the grid by means of a reversible static power frequency converter (inverter/rectifier) [4]. The high sensitivity of the DFIG to electrical faults reveals numerous difficulties in terms of conformance to specifications imposed by the electrical grid managers [2]. Defects appearing in an electrical system have various causes. They may be due to the aging of the system components (electronic components, machine coils) or to conditions of use or simply to a manufacturing defect whose effect would be imperceptible during commissioning [5], [6].

In a static converter feeding DFIG (two level inverter), a severe defect in an element of the energy conversion chain alone can cause the total or partial loss of the system control (DFIG+inverter). In this paper, Lissajous curves will be presented as a diagnosis method for detecting the inverter feeding doubly fed induction generator in the case of single and multiple short circuit switches faults. The proposed method has shown its effectiveness in several fields like the rotating machinery [7], faults diagnosis [8]-[10], it was also studied in the case of multiple open switches faults in three phase voltage inverter feeding DFIG presented in a previous paper [11]. 


\section{WIND TURBINE MODELING}

According to the theory of momentum and Bernoulli's theorem, incident theoretical power due to wind $P_{\text {wind }}$ is given by the equation as shown in (1).

$$
P_{\text {wind }}=\frac{1}{2} \rho * \mathrm{~A} * v^{3}
$$

Where A: Sweep area swept by the blade,

P: Density of air, $1.225 \mathrm{~kg} / \mathrm{m}^{3}$,

v: Wind speed,

The expression of the mechanical power captured by the blade [12] is (2).

$$
P_{\text {turbine }}=\frac{1}{2} * C_{\mathrm{p}} * \rho * \mathrm{~A} * v^{3}
$$

Where $C_{\mathrm{p}}$ is the coefficient of power.

According to [13], [14] this last coefficient is approximated by (3).

$$
C_{\mathrm{p}}(\lambda, \beta)=0.4233 \sin \left(\frac{\pi(\lambda-3)}{15-0.3 \beta}\right)-0.0184(\lambda-3) \beta
$$

Where $\lambda$ : specific speed,

$\beta$ : angle of the blades orientation.

Then the aerodynamic torque is written (4) [15].

$$
C_{\text {aero }}=\frac{P_{\text {turbine }}}{\Omega}=\frac{1}{2} \frac{C_{p} * \rho * \pi * R^{2} * V^{3}}{\Omega}
$$

The multiplier assures adaptation of the slow speed of the blades to the fast speed of the machine by the gain G. The mechanical torque $\mathrm{Cm}$ and the speed of the machine $\Omega_{r}$ are presented respectively in (5) and (6):

$$
\begin{aligned}
& C_{m}=C_{\text {aero }} / G r \\
& \Omega_{r}=G * \Omega
\end{aligned}
$$

The fundamental equation of dynamics is given by (7).

$$
J \frac{d \Omega_{r}}{d t}=\frac{J}{\mathrm{p}} \frac{d w_{r}}{d t}=\mathrm{C}_{m}-\mathrm{C}_{e m}-\mathrm{C}_{v i s}=C_{m}-C_{e m}-f * \Omega_{r}
$$

Where $J$ : Total inertia that appears on the generator shaft

$\mathrm{P} \quad$ : number of pole pairs

$\Omega_{r} \quad$ : Electrical angular speed of the rotor

$C_{e m}:$ Electromagnetic torque

$C_{v i s} \quad:$ Viscous friction torque

$f \quad$ : Coefficient of viscous friction

\section{MODELING OF DOUBLY FED INDUCTION GENERATOR}

Model of the asynchronous machine equations for the stator $V_{s}$ and the rotor $V_{r}$ voltages in Park reference frame $(d, q)$ are given by (8) [16].

$$
\begin{aligned}
& \left\{\begin{array}{l}
V_{s d}=R_{s} * I_{s d}+\frac{d}{d t}\left(\varphi_{s d}\right)-\omega_{s} * \varphi_{s q} \\
V_{s q}=R_{s} * I_{s q}+\frac{d}{d t}\left(\varphi_{s q}\right)-\omega_{s} * \varphi_{s d}
\end{array}\right. \\
& \left\{\begin{array}{l}
V_{r d}=R_{r} * I_{r d}+\frac{d}{d t}\left(\varphi_{r d}\right)-\left(\omega_{s-} \omega_{r}\right) * \varphi_{r q} \\
V_{r q}=R_{r} * I_{r q}+\frac{d}{d t}\left(\varphi_{r q}\right)-\left(\omega_{s-} \omega_{r}\right) * \varphi_{r d}
\end{array}\right.
\end{aligned}
$$


The electromagnetic torque equation is presented as shown in (9).

$$
C_{e m}=-\frac{3}{2} p * \frac{L_{m}}{L_{s}}\left(\varphi_{r d} * I_{r q}-\varphi_{r q} * I_{s d}\right)
$$

\section{FIELD ORIENTED CONTROL}

In order to perform the DFIG active and reactive power by controlling dynamically and separately the flux and the torque, we choose orienting the stator flux along the direct axis and obtain:

$$
\begin{aligned}
& \left\{\begin{array}{l}
\varphi_{d s}=\varphi_{s} \\
\varphi_{q s}=0
\end{array}\right. \\
& C_{e m}=-P \cdot \frac{M}{L_{s}} \varphi_{d s} \cdot i_{q r}
\end{aligned}
$$

Active and reactive powers can be written is being as (10).

$$
\left\{\begin{array}{l}
P_{r}=g \frac{V_{s} * M}{L_{s}} * i_{q r} \\
Q_{r}=g \frac{V_{s} * M}{L_{s}} * i_{d r}
\end{array}\right.
$$

\section{VOLTAGE SOURCE INVERTER SYSTEM}

Voltage source inverter (VSI) is an electronic device that relates direct current (DC) to alternating current (AC). VSI has benefits such as higher efficiency, reduced installation time, elimination of interconnect power wiring costs and reduced building floor space [17]. In a wind energy conversion system using a doubly fed induction generator, as can be seen from Figure 1 [18], a fixed DC input voltage is supplied to the inverter and a controlled AC output voltage is achieved by setting the on and off periods of the inverter switches.

In this application, we are interested in the hypo-synchronous operation of the generator, so as to treat only the transfer of rotor power in one direction (grid to rotor). The grid side converter will therefore be a simple unidirectional rectifier. The DC bus voltage is therefore kept fixed and we are interested only in the control of the rotor side converter [11].

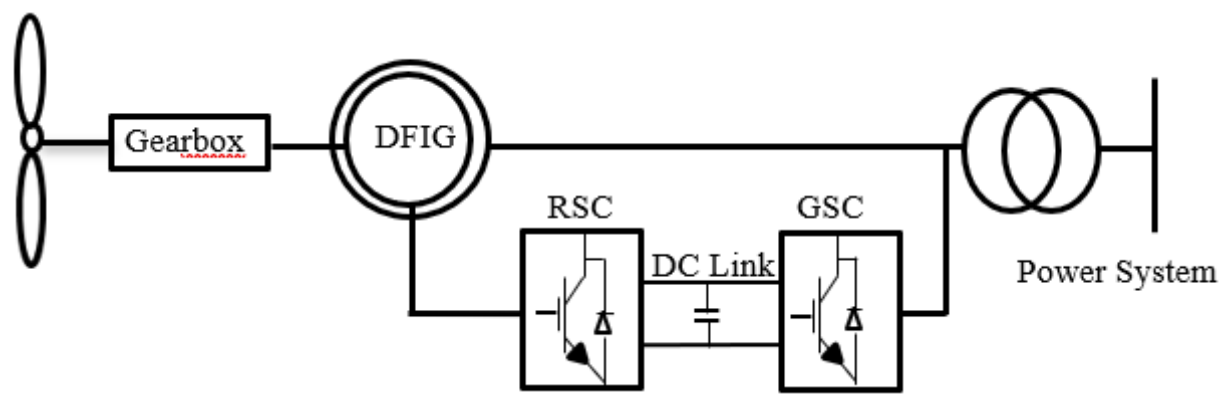

Figure 1. Wind energy conversion system using a doubly fed induction generator

\section{LISSAJOUS CURVES FOR DFIG DEFECTS DIAGNOSIS}

Lissajous curve is the trajectory of a point whose rectangular components have a sinusoidal movement, the $\mathrm{x}$ signal and the $\mathrm{y}$ signal are both described separately by different sine waves. So, by expressing $\mathrm{y}$ as a function of $\mathrm{x}$, different patterns are created. In order to apply these curves to the DFIG rotor currents, it is necessary to use the Concordia transformation [19] on the three-phase rotor basic currents $I_{r a b c}$ to obtain the rotor currents Concordia components $\left(I_{r \alpha}, I_{r \beta}\right)$ such as:

$$
\left[\begin{array}{l}
I_{r \alpha} \\
I_{r \beta}
\end{array}\right]=\frac{\sqrt{2}}{3}\left[\begin{array}{ccc}
1 & -1 / 2 & -1 / 2 \\
0 & \frac{\sqrt{3}}{2} & -\frac{\sqrt{3}}{2}
\end{array}\right] *\left[\begin{array}{l}
I_{r a} \\
I_{r b} \\
I_{r c}
\end{array}\right]
$$




\section{SIMULATION RESULTS}

Simulation of the energy conversion chain was performed using MATLAB $^{\wedge}$ - Simulink $^{\wedge}$ software. It allowed us to create multiple fault scenarios that could appear in the converter switches (single fault, double fault in the same leg or in different legs, possibility of cascades of defects of the same nature or different).

\subsection{Free-defects operation}

The Lissajous curve of doubly fed induction generator rotor currents Concordia components, as shown in Figure 2, has a shape of two circles of which the one inside has six knots: the number of the inverter switches. Subsequently, cases of defected inverter feeding the DFIG will be compared with this case reference.

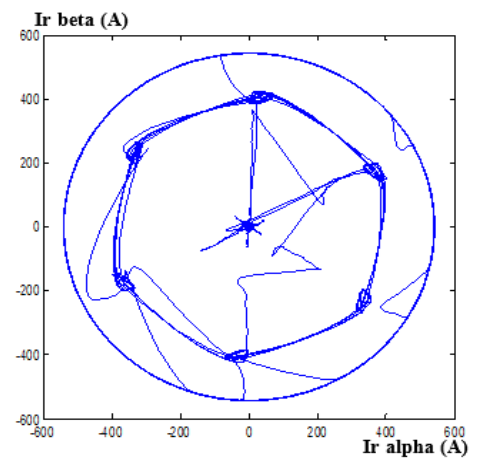

Figure 2. Lissajous curve of a DFIG rotor currents during free-defects operation

\subsection{Faulty operation}

Various failures can impact the inverter during its operation, especially in terms of its so-called power components because of their fragility [20]. Two types of faults can be signalted: short circuit and open circuit faults [21], [22]. Note that a fault in an inverter feeding an asynchronous machine can cause significant consequences on the mechanical level: the ripple of the torque and the speed bring undesirable vibrations and annoying sound noises [5]. In some cases, the system is able to operate but with degraded performance (operates with imbalance in electrical and mechanical quantities and with low gain). In this paper, the rotor side converter faulty operations are considered in the case of multiple short-circuits switches faults that occur at the same leg and at different legs as can be seen from Figure 3 [23]. The short circuit fault condition occurs when one of the switching cell components (insulated gate bipolar transistor (IGBT) in our case study) stays closed constantly $\left(S_{i}=1\right)$.

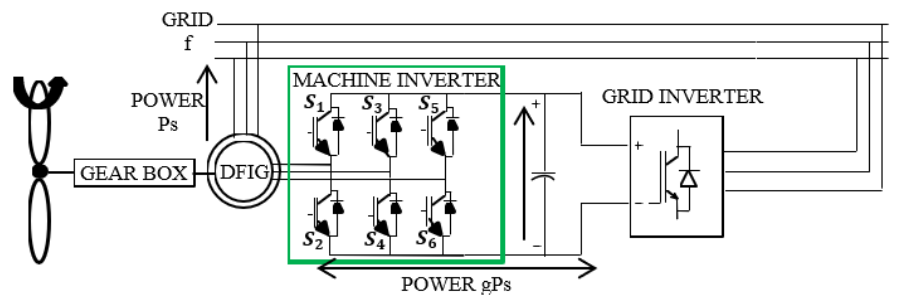

Figure 3. The six switches $\left\{S_{1}\right.$ to $\left.S_{6}\right\}$ of the rotor side converter concerned by the faulty operation study

Short-circuit faults can be considered as the most serious faults attacking the IGBT switches [24]. The current in the presence of this fault attains limits that can lead to the fusion of its chip or its connection. If the fault detection does not took place quickly (less than 10 microseconds), then the active IGBT switch on the same leg goes through the same phenomenon and therefore the entire leg of the inverter is shorted [25]. Note that this type of fault causes disturbed and unstable operation of the system due to the operating mode change during the application of the fault. 
Indeed, short circuit fault can introduce a decrease in speed to a value almost zero in certain intervals with the presence of undulations, and increasing torque and currents to intolerable levels in other intervals. This allows us to say that this defect alone can cause enormous damage to the entire wind turbine conversion chain. Simulation results of the DFIG fed by a three-phase voltage inverter controlled in sinetriangular PWM are obtained. The Lissajous curves of rotor currents Concordia components indicate the inverter faulty situation.

\subsection{Inverter single switch fault}

The Figures 4 (a) and (b) show the rotor currents Lissajous curve in the case of different level single switch fault. When the fault occurs, the resulting shape is close to a circle with five knots with more concentration on one of the existing knots whose position depends on the defected switch location. In the case of one upper switch fault, the concentration is on the knot at the top Figure 4 (a). In the case of one lower switch fault, the concentration is on the knot at the bottom Figure 4 (b).

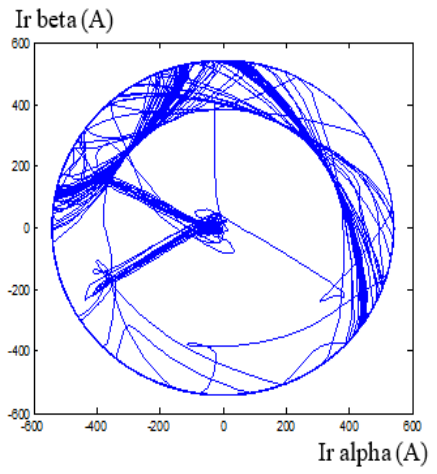

(a)

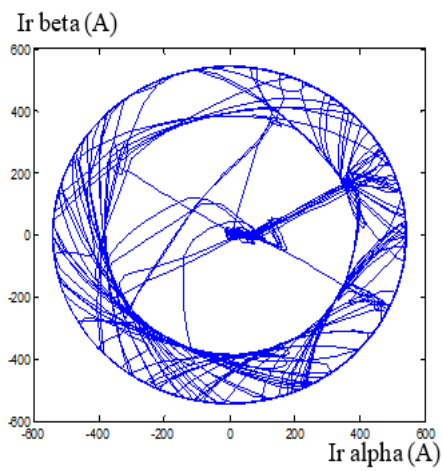

(b)

Figure 4. Lissajous curves of rotor currents Concordia components (a) case of a DFIG fed by $S_{1}$ switch defected inverter and (b) case of a DFIG fed by $S_{2}$ switch defected inverter

\subsection{Inverter double switches fault in the same leg}

The Figures 5 (a)-(c) show the rotor currents Lissajous curve in the case of the same leg double switches faults. When the fault occurs, the resulting shape is close to a circle with four knots forming a butterfly with knot inside Figure 5 (a) until Figure 5 (c). The obtained shape changes its orientation according to the defected switches location.

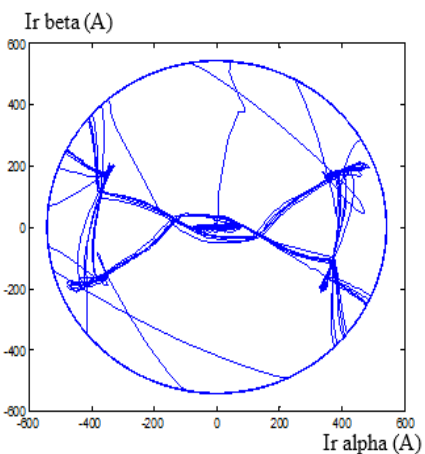

(a)

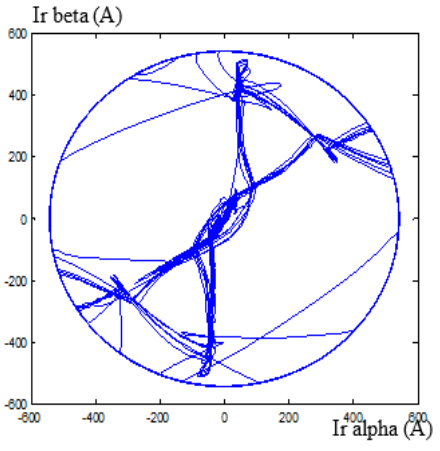

(b)

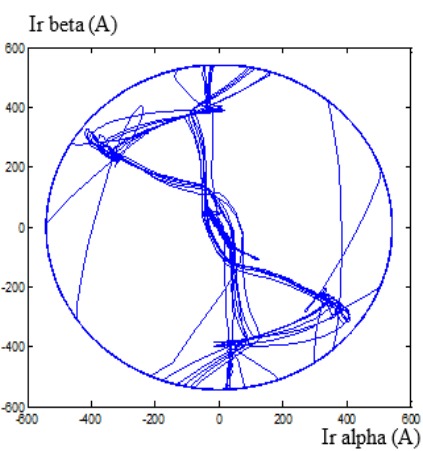

(c)

Figure 5. Lissajous curves of rotor currents (a) case of a DFIG fed by $S_{1}$ and $S_{2}$ switches defected inverter,

(b) case of a DFIG fed by $S_{3}$ and $S_{4}$ switches defected inverter, and (c) case of a DFIG fed by $S_{5}$ and $S_{6}$ switches defected inverter

\subsection{Inverter double switches fault in different legs}

The Figures 6 (a)-(c) show the rotor currents Lissajous curves in the case of different leg double switches fault. When the faults occur, the resulting shape is close to a circle with four knots instead of six

Diagnosing multiple short circuit switches faults in wind turbine doubly-fed induction ... (Sara Kharoubi) 
Figure 6. The circle missed knots changes its orientation according to the defected switches location. In the case of two upper switches fault, the missed knots appear at the bottom Figure 6 (a). In the case of two lower switches fault, the missed knots appear at the top Figure 6 (b). In the case of one upper switch and one lower switch faults, the two missed knots appear one at the top and the second at the bottom as shown in Figure 6 (c).

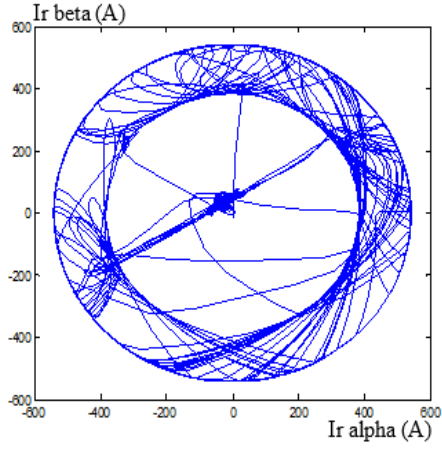

(a)

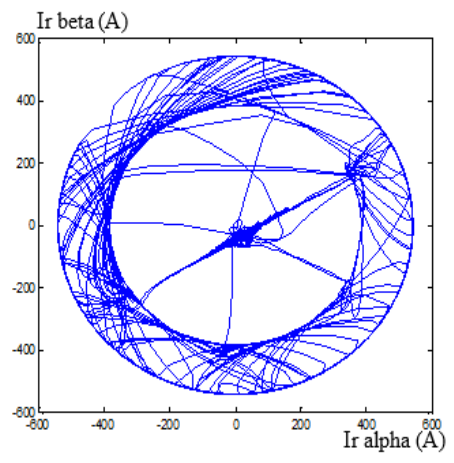

(b)

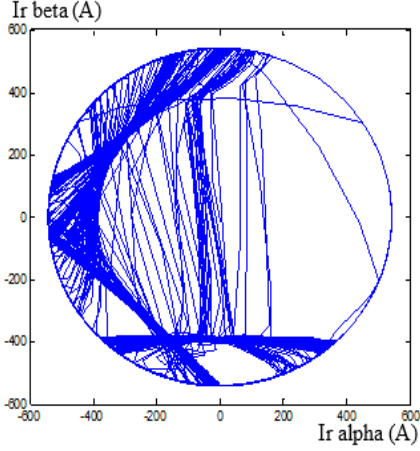

(c)

Figure 6. Lissajous curve of rotor currents (a) case of a DFIG fed by $S_{1}$ and $S_{3}$ switches defected inverter, (b) case of a DFIG fed by $S_{2}$ and $S_{4}$ switches defected inverter, and (c) case of a DFIG fed by $S_{1}$ and $S_{4}$ switches defected inverter

\section{CONCLUSION}

The work presented in this paper is devoted to the analysis, modelling and simulation of a variable speed wind turbine using a doubly fed induction generator DFIG. In the first part, we gave a brief description of the VSI, its operating principle and its advantages. In the second part, we studied simulation results of the inverter feeding the DFIG in the case of single and multiple short circuit switches faults. Several fault scenarios are applied and visualized using the method of Lissajous curves of DFIG rotor currents Concordia components which shows the defect exact location. In the case of a free-defects operation, the Lissajous curves have a shape of two circles of which the one inside has six knots (corresponding to the number of the inverter switches). The width of the circle connecting the 6 knots positions differs, the number of knots decreases, and the orientation of the circle changes depending on the number of the inverter defected switches and their position. The next work will deal with other powerful diagnostic methods that will be associated to the Lissajous curves method to determine the severity of the defect encountered and thus remedy this problem to avoid unwanted consequences.

\section{REFERENCES}

[1] M. A. El-Sharkawi, "Wind energy,” University of Washington, Seattle, USA, 2016.

[2] M. Smaili, "Modélisation et commande d'un aérogénérateur à machine asynchrone à double alimentation en vue de simulation des problèmes de cogénération," Université Du Quebec En Aritibi-Temiscamingue, 2013.

[3] H. Abu-Rub, M. Malinowski, and K. Al-Haddad, "Power electronics for renewable energy systems, transpotation and industrial applications," John Wiley \& Sons, Ltd, 2014.

[4] G. Abad, J. Lopez, M. A. Rodiguez, L. Marroyo, and G. Iwanski, "Doubly fed induction machine modeling and control for wind enegy generation," John Wiley \& Sons, vol. 85, 2011.

[5] N. Aouane and S. Chamkha, "Détection, localisation et reconfiguration de défauts onduleur à deux niveaux appliqué dans la commande de la machine asynchrone à cage," Faculté Des Sciences De l'Ingénieur, Université M'hamed Bougara-Boumerdes, Algérie, Juin 2017.

[6] J. C. Trigeassou, "Diagnostic des machine électriques," Lavoisier, 2011

[7] H. A. H. Al-Khazali and M. R. Askari, "Geometrical and Graphical Representations Analysis of Lissajous Figures in Rotor Dynamic System," Journal of Engineering (IOSR), vol. 2, no. 5, pp. 971-978, May 2012, doi: 10.9790/3021-0205971978.

[8] L. El Menzhi and A. Saad, "Lissajous Curve of an Auxiliary Winding Voltage Park Components for Doubly-Fed Induction Machine Electrical Faults Diagnosis," The Journal of Advanced Materials Research, vol. 860, pp. 2223-2231, 2014, doi: 10.4028/www.scientific.net/AMR.860-863.2223.

[9] F. El Hammouchi, L. El Menzhi, A. Saad, Y. Ihedrane, and B. Bossoufi, "Wind turbine doubly-fed asynchronous machine diagnosis defects using stator and rotor currents lissajous curves," International Journal of Power Electronics and Drive System (IJPEDS), vol. 10, no. 2, pp. 961-970, June 2019, doi: 10.11591/ijpeds.v10.i2.pp961-970.

[10] F. EL Hammouchi, L. El Menzhi, and A. Saad, "Diagnosis Method for Wind Turbine Doubly Fed Induction Generator under Grid Defects," International Journal of Information Science \& Technology-IJIST, vol. 3 no. 3, pp. 46-55, 2019. 
[11] S. Kharoubi and L. El Menzhi, "Wind turbine doubly-fed induction generator defects diagnosis using rotor currents Lissajous curves," International Journal of Power Electronics and Drive System (IJPEDS), vol. 11, no. 4, pp. 2083-2090, December 2020, doi: 10.11591/ijpeds.v11.i4.pp2083-2090.

[12] O. Anaya-Lara, N. Jenkins, J. Ekanayake, P. Cartwright, and M. Hughes 'Wind energy generation: Modeling and control," Jhon Wiley \& Sons, Ltd, UK, 2011.

[13] M. Adjoudj, M. Abid, A. Aissaoui, Y. Ramdani, and H. Bounoua, "Commande par Mode Glissant d'une Machine Asynchrone à Double Alimentation Monté dans une Eolienne," Revue Nature et Technologie, no. 2, pp. 27-34, 2010.

[14] F. M. Hughes, O. Anaya-Lara, N. Jenkins, and G. Strbac, "Control of DFIG-based wind generation for power network support," in IEEE Transactions on Power Systems, vol. 20, no. 4, pp. 1958-1966, Nov. 2005, doi: 10.1109/TPWRS.2005.857275.

[15] L.Leclercq, "Apport du stockage inertiel associé à des éoliennes dans un réseau électrique en vue d'assurer des services systèmes," Doctoral thesis, Central School of Lille, December 2004.

[16] P. B. Varvadiya, P. D. Patal, and A. McEwan, "Measurement of the speed of sound in air medium using Lissajous Patterns," SSRG International Journal of Electrical and Electronics Engineering (SSRG-IJEEE), vol. 2, no. 11, pp. 5-8, Nov. 2015, doi: 10.14445/23488379/IJEEE-V2I11P102.

[17] N. S. Ahmad, A. R. Abdullah, N. Bahari, "Open and short circuit switches fault detection of voltage source inverter using spectrogram," Journal of International Conference on Electrical Machines and Systems, vol. 3, no. 2, pp. 190-199, 2014, doi: 10.11142/jicems.2014.3.2.190.

[18] B. Qin, H. Li, X. Zhou, J. Li, and W. Liu, "Low-Voltage Ride-Through Techniques in DFIG-Based Wind Turbines: A Review," Appl. Sci., vol. 10, no. 6, p. 2154, 2020, doi: 10.3390/app10062154.

[19] B. Bossoufi, M. Karim, S. Ioniłă, and A. Lagrioui, "Performance analysis of the direct torque control and the space vector modulation for permanent magnet synchronous motor drive," University of Pitesti Scientific Bulletin: Electronics and Computers Science, vol. 10, no. 2, pp. 23-34, 2010.

[20] R. Singh, K. Fink, and I. W. Hao, "Operation of a Digitally-Controlled IGBT Gate-Driver with Advance Protection Features During Short-Circuit Type II Conditions," PCIM Asia 2020; International Exhibition and Conference for Power Electronics, Intelligent Motion, Renewable Energy and Energy Management, 2020, pp. 1-7.

[21] W. Zhang, D. Xu, P. N. Enjeti, H. Li, J. T. Hawke, and H. S. Krishnamoorthy, "Survey on Fault-Tolerant Techniques for Power Electronic Converters," in IEEE Transactions on Power Electronics, vol. 29, no. 12, pp. 6319-6331, Dec. 2014, doi: 10.1109/TPEL.2014.2304561.

[22] S. Oommen, A. Ballaji, M. Kumar, and B. Ankaiah, "Fault Analysis in Inverter Fed Induction Motor Drive System due to Switch Failures," Journal of Xi'an University of Architecture \& Technology, vol. 12, no. 4, pp. 3936-3944, 2020.

[23] F. Potiers, T. Bouaouiche, and M. Machmoum, "Advanced control of a doubly-fed induction generator for wind energy conversion," Electric Power Systems Research, vol. 79, no. 7, pp. 1085-1096, July 2009, doi: 10.1016/j.epsr.2009.01.007.

[24] M. H. Mohamed Sathik, P. Sundararajan, F. Sasongko, J. Pou, and V. Vaiyapuri, "Short Circuit Detection and Fault Current Limiting Method for IGBTs," in IEEE Transactions on Device and Materials Reliability, vol. 20, no. 4, pp. 686-693, Dec. 2020, doi: 10.1109/TDMR.2020.3018717.

[25] B. D. E. Cherif and A. Bendiabdellah, "Detection of Two-Level Inverter Open-Circuit Fault Using a Combined DWT-NN Approach," Journal of Control Science and Engineering, vol. 2018, 2018, doi: 10.1155/2018/1976836.

\section{BIOGRAPHIES OF AUTHORS}

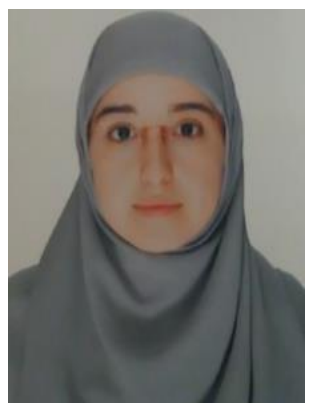

Sara Kharoubi (iD 88 SC P was born in Morocco on September 9th, 1991. In 2015, She received the Engineer degree in Mechatronic Engineering from the National School of Applied Sciences (ENSA) Abdelmalek Essaadi University of Morocco in Tétouan. She is a Ph.D student in electrical engineering at Innovative Technologies Laboratory (LTI) of ENSA Tangier since December 2016. She is interested in electrical machines control, on line diagnosis defects in wind turbines, and their integration in grid. She can be contacted at email: sara.kharoubi@gmail.com.

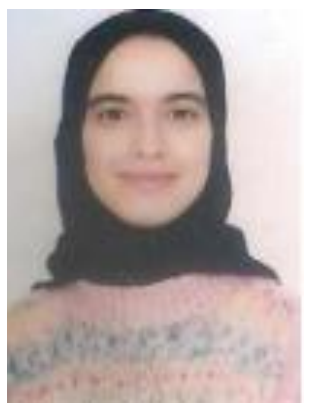

Lamiaa El Menzhi (D) SC P is a professor in Abdelamalek Essaadi University in Morocco since 2010. On 2002, She got her High Deepened Studies Diploma in electrical machines in electrical engineering from the High National School of Electricity and Mechanics ENSEM in Hassan 2 University in Casablanca. From 2002 until 2004, she was a research student in one of the universities in japan. On 2009, she obtained her Doctor degree, then her Habilitation as a professor researcher on 2016 from Hassan 2 University in Casablanca (ESEM). She is interested in electrical machines control and on-line diagnosis either used as a motor or a generator in wind turbines. Lamiaa El Menzhi is a member and advisor of the Moroccan Center of Polytechnical Research and Innovation since 2015. She can be contacted at email: lam.elmenzhi@gmail.com. 